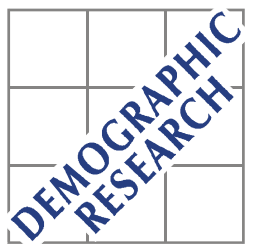

Demographic Research a free, expedited, online journal of peer-reviewed research and commentary in the population sciences published by the Max Planck Institute for Demographic Research Konrad-Zuse Str. 1, D-18057 Rostock · GERMANY www.demographic-research.org

DEMOGRAPHIC RESEARCH

SPECIAL COLLECTION 3, ARTICLE 5

PUBLISHED 17 APRIL 2004, PAGES 117-134

www.demographic-research.org/special/3/5/

DOI: 10.4054/DemRes.2004.S3.5

Research Article

\title{
Step-families and Childbearing Desires in Europe
}

\section{Elizabeth Thomson}

This special collection is in honor of Jan M. Hoem on his $65^{\text {th }}$ birthday. The authors presented their papers at a working party at the Max Planck Institute for Demographic Research in Rostock, Germany in April 2004. The collection is edited by Gunnar Andersson and Gerda Neyer.

(C) 2004 Max-Planck-Gesellschaft. 


\section{Table of Contents}

$1 \quad$ Introduction: step-families and childbearing desires $\quad 118$ in Europe

$2 \quad$ Values of children and step-family childbearing 118

3 The evidence to date 121

$4 \quad$ Further evidence on stepfamily fertility in Europe: $\quad 122$ data and methods

$\begin{array}{llr}5 & \text { Results } & 125\end{array}$

6 Discussion and conclusions $\quad 129$

$7 \quad$ Acknowledgements 130

$\begin{array}{ll}\text { Notes } & 131\end{array}$

$\begin{array}{lr}\text { References } & 132\end{array}$ 


\title{
Step-families and Childbearing Desires in Europe
}

\author{
Elizabeth Thomson ${ }^{1}$
}

\begin{abstract}
Increases in union stability and non-union childbearing during the latter half of the $20^{\text {th }}$ century produced substantial increases in the prevalence of step-families. Research on step-family fertility in several European countries and the United States show that, net of a couple's combined number of children (hers, his and theirs), birth risks are elevated when the child is the couple's first or second. These patterns have been interpreted in terms of unique values of first and second shared children that overcome costs of rearing larger numbers of children in stepfamilies. Such inferences require that all births are wanted or that unwanted births are as likely for couples with as for those without stepchildren. Analyses of several European fertility and family surveys show that previously observed patterns of stepfamily childbearing are replicated in desires for another child, providing stronger support for motivational explanations of childbearing patterns in step-families.
\end{abstract}

Department of Sociology and Center for Demography and Ecology, 1180 Observatory Drive, University of Wisconsin-Madison, Madison, WI 53706 USA. E-mail: thomson@ssc.wisc.edu. Also: Department of Sociology, Stockholm University, SE 10691 Stockholm, Sweden. 


\section{Introduction: step-families and childbearing desires in Europe}

A key feature of changing family behavior and structures in Europe is the increased prevalence of stepfamilies. By age 35, the likelihood that a woman will enter a first or second union after having children ranges from a low of 4 percent in Italy to a high of 38 percent in the former German Democratic Republic (Prskawetz et al. 2003) (Note 1). These percentages underestimate the prevalence of stepfamilies because they do not include childless women who form unions with men who already have children. Because most of these families are formed during the partners' childbearing years, they are at risk of having more children together.

Several recent studies in Europe and the United States have shown that stepfamily formation produces "extra" births; that is, net of the total number of children born to a woman, her partner or the couple together, birth risks are elevated when the prospective child will be the couple's first or second (Thomson 1997, Vikat, Thomson and Hoem 1999, Buber and Prskawetz 2000, Henz 2002, Olah 2001, Thomson et al. 2002, Thomson and Li 2002). These patterns have been interpreted in terms of the unique values of first and second shared children that overcome the costs of rearing larger numbers of children in stepfamilies. Inferences about motives based on parity progressions assume that all births are intended or that stepfamily couples are no more or less likely to have unintended births than are couples without stepchildren. Similar patterns have been found for birth intentions in a small number of studies (Thomson 1997, Toulemon and LaPierre-Adamchk 1995, Thomson and Li 2002).

In this paper, I provide further evidence for the value of first and second births to couples by investigating prospective childbearing desires. Analyses are based on six countries - Austria, Finland, France, Germany, Latvia and Slovenia. Because the data were collected shortly after German reunification and because fertility patterns in the former GDR and Federal Republic of Germany do not appear to be converging (Kreyenfeld 2003), East and West Germany are treated as two separate countries. Although the selection of countries for comparison is based on data availability, they represent a reasonably wide spectrum of life course pathways to stepfamily formation (Prskawetz et al. 2003).

\section{Values of children and step-family childbearing}

In low-fertility societies, unique values of first and second children are the primary mechanism for maintaining replacement-level fertility. Because children provide few economic benefits to their parents while requiring high expenditures of time and 
financial resources, the question arises: Why have children? Now classic studies of the 'value of children' demonstrated that first and second children provide unique social and psychological benefits that for most people outweigh the childrearing costs (Bulatao 1981, Fawcett 1983, see summary in Thomson 2002a). A first birth confers adult status and creates close ties to kin, community and society (parental status value). To the extent that women have fewer alternative sources of adult status than men, the maternal status value of a first birth may be greater than its paternal status value. Many couples also see the first child as establishing them as a family; the child represents the couple's commitment to their relationship and to rearing the child together (commitment value). Second children are valued primarily as siblings for the first (sibling value). The unique benefits of first and second children are reflected in very high rates of first and second births, compared to third and higher-order births in wealthy societies.

Stepfamilies present an interesting puzzle for fertility researchers. First births to stepfamily couples should also be valued as demonstrating the couple's commitment and creating a family. But at least one of the partners in a stepfamily has already achieved the status of biological parent, and step-parenthood may confer a degree of parental status as well, so the combined value is somewhat less than for births to couples without stepchildren. In addition, the step-family couple must weigh the value of a first shared birth against the cost of rearing at least two children rather than one. If there were no added value provided by a first shared child - to represent the couple's commitment and/or confer the status of biological parenthood on one of the partners we would expect stepfamilies to have lower first birth rates than couples without stepchildren. Differences in the value of maternal and paternal status might also produce variability in step-family childbearing depending on which partner has children from a previous union.

Similar issues arise for the decision to have a second shared child. In step-families, the couple's first shared child is born with at least one half-sibling; if they produce a full sibling, step-family couples will end up with at least three children altogether. If no unique extra value is produced by a second shared child, again, we would expect stepfamilies to be less likely to have one.

Table 1 summarizes these arguments, identifying hypothetical values of a prospective birth for couples with different combined numbers of children and different configurations of step- and shared children. Because the couple's combined parity is directly associated with childrearing costs (Bulatao 1981), variations in childbearing desires or intentions associated with different combinations of shared and separate children tell us something about the values associated with the prospective birth. First births to couples without any children at all may arise from both commitment and parental status value. The interesting comparisons arise when couples have at least one 
child, hers, his or theirs. Among couples with one child, those with a shared child are considering the value of a sibling, while those with a separate (step) child are considering the commitment value of a first shared child and biological parental status for one of the partners. We might find no differences in desires for another child between these two types of couples because the different types of value are equivalent in motivational strength. We can, however, identify differences between step-family couples that would arise from differences in the value of biological parenthood to men and to women.

Table 1: $\quad$ Hypothesized values of next birth by stepfamily parities

\begin{tabular}{|c|c|c|c|c|}
\hline Parity combinations & Combined ( $\mathrm{h}$ & is + their) parit & & \\
\hline \multirow[b]{2}{*}{ No stepchildren } & zero & one & two & three or more \\
\hline & $\begin{array}{l}\text { commitment } \\
\text { parenthood }\end{array}$ & sibling & & \\
\hline $\begin{array}{l}\text { Only her } \\
\text { child(ren) }\end{array}$ & n.a. & $\begin{array}{l}\text { commitment } \\
\text { fatherhood }\end{array}$ & $\begin{array}{l}\text { commitment } \\
\text { fatherhood }\end{array}$ & $\begin{array}{l}\text { commitment } \\
\text { fatherhood }\end{array}$ \\
\hline $\begin{array}{l}\text { Only his } \\
\text { child(ren) }\end{array}$ & n.a. & $\begin{array}{l}\text { commitment } \\
\text { motherhood }\end{array}$ & $\begin{array}{l}\text { commitment } \\
\text { motherhood }\end{array}$ & $\begin{array}{l}\text { commitment } \\
\text { motherhood }\end{array}$ \\
\hline Hers, his, no shared & n.a. & n.a. & commitment & commitment \\
\hline $\begin{array}{l}\text { Stepchild(ren) } \\
\text { and one shared }\end{array}$ & n.a. & n.a. & (full) sibling & (full) sibling \\
\hline $\begin{array}{l}\text { Stepchild(ren) and } \\
\text { two or more shared }\end{array}$ & n.a. & n.a. & n.a. & \\
\hline
\end{tabular}

At higher combined parities, more information about childbearing motives is provided by comparisons between couples with different numbers of shared children. Couples with two or more shared children are the reference group, having acquired all of the unique benefits of first and second shared children. Couples with stepchildren but no shared children may be motivated by the commitment value of a first shared child and, if all of the stepchildren are those of one partner, by the value of maternal or paternal status. Couples with one shared child may be motivated by the value of a full sibling to have another child. Note that at combined parity three or more, some stepfamily couples will have acquired the unique values associated with first and second shared births. 


\section{The evidence to date}

Most studies of step-family fertility have not attended carefully to parity, either the man's or the woman's. As I argued above, the number of children for which the couple has childrearing responsibilities is a key determinant of childrearing costs. As a result, among couples with only shared children, three-child families are unusual and larger families are rare. Thus, if one simply estimated the effects of having stepchildren or the number of stepchildren on the risk of a first or second shared birth, the effects are likely to be negative; the more stepchildren, the greater are costs of having another child (e.g., Bumpass 1984, Wineberg 1990, Lillard and Waite 1993, Loomis and Landale 1994, Stewart 2002). Only when we find that the number of stepchildren, especially two or more stepchildren, has no effect on the risk of a first shared birth (e.g., Griffith, Koo and Suchindran 1985, Toulemon 1997, Vikat et al. 1999), may we infer that the shared child has unique value to the couple.

A more fruitful model for understanding step-family fertility is found in two Swedish studies (Hoem 1995, Vikat et al. 1999). Parity-specific birth risks were specified as a function of the number of previous children born in the current union. Taken together, the parity-specific models test the interaction between shared parity and the respondent's parity. In both studies, the risk of women's and men's second and third births were significantly greater if the couple had no shared children, i.e., the birth was the first in the union. Vikat et al. (1999) found also that third birth risks were higher if the third birth was the second in the union. These results provide some support for the commitment value of a first shared birth and mixed results relevant to the value of full siblings. Neither study included information on the partner's children, meaning that, on average, childrearing costs were underestimated. Thus, the increased birth risks observed are lower-bound estimates of the added value of first and second shared births.

The ideal data for understanding step-family fertility include information on both partners' separate children. It is then possible to specify potential differences between each of the theoretically useful cells of Table 1. In a previous study, several colleagues and I (Thomson et al. 2002) developed a model of combined parity and combinations of shared and separate children to test hypotheses about the commitment, parental status and sibling values of first and second shared births. We excluded couples with no children or stepchildren because they provide no comparison that is theoretically relevant to the child values motivating step-family couples to have additional births (cf. Table 1). Our model pooled all birth intervals and controlled for the couple's combined parity. In Austria, Finland, France and West Germany, we found that step-family couples with no shared child or only one shared child had a higher birth risk than would be expected given their combined parity. We did not, however, find higher birth risks for couples in which one of the partners was not a parent before the step-family formed 
than for couples in which both partners were parents. The results are consistent with commitment and sibling values of shared children but not with the value associated with parental status. It could be that non-parents entering step-families have unobserved characteristics negatively associated with childbearing or that step-parenthood provides an adequate substitute for biological parenthood. (See also studies by Toulemon 1997, Buber and Prskawetz 2000, Henz 2000, Olah 2001).

In a subsequent analysis of U.S. data (Thomson and Li 2002), I extended this model to deal with the association between combined parity and step-family composition. That is, if both partners are parents, or if the couple has shared and stepchildren, their combined parity must be two or more; if they have two or more shared children, their combined parity must be three or more. The model estimates stepfamily composition separately for couples with combined parity one, two, three or more. Not only were effects of step-family composition similar to those estimated in Europe for birth risks, but parallel results were found for birth intentions and couples' birth intentions accounted for most of the step-family effects on the birth risk. These results strengthen inferences about underlying motivations for step-family childbearing. (See also Toulemon and LaPierre-Adamchk 1995.)

\section{Further evidence on stepfamily fertility in Europe: data and methods}

In this study, I apply the Thomson-Li (2002) specification to childbearing desires in seven countries that participated in the recent European Fertility and Family Surveys and for which appropriate data on family composition are available: Austria, Finland, France, East Germany, West Germany, Latvia and Slovenia (Note 2). Together, they provide considerable variation in patterns of step-family formation. I used the Standard Recode File for each country (UNECE 2003).

In order to test hypotheses about motivations behind step-family childbearing, one must have sufficient numbers of step-families of different configurations to estimate differences in childbearing desires. I had to exclude countries with extremely small proportions of step-families (cf. Prskawetz et al. 2003). Among the remaining countries, data comparability determined which could be included. Although the European Fertility and Family Surveys were designed for comparative analysis, some of the surveys were conducted before the full protocol was developed and others varied in the degree to which modifications were made to the common interview schedule. In all countries, it is relatively straightforward to classify the respondent's children as shared or separate children based on their birth dates and the date of union formation (see detail below). 
Data on partners' children come from two sources: a question in the partner history about the number of children the partner had at time of union formation; and a child history that purports to include the respondent's stepchildren from current or former unions. In almost every country where information was available from both sources, the child history produced significantly smaller numbers of stepchildren than did the question on partner's children at union formation. In some surveys, respondents were instructed to include only children they had raised; in others, it appears that they may have interpreted the broader question to exclude children with whom they had little or no contact. I therefore used only the question on partner's children at union formation to determine the couple's combined parity and step-family composition. This decision led to the exclusion of several countries (Canada, Lithuania, New Zealand, Norway) with high proportions of step-families because the survey did not ask about partner's children at the time of union formation.

The respondents' children were classified as shared if they were born in the current union or during the 12 months before that union; only a handful of such children were born within 9 months of a previous union. This decision rule matches that used in analyses of birth and union histories (Thomson et al. 2002) and recognizes that children raised from infancy are highly likely to be viewed as shared children, even if one of the partners is not the child's biological parent. Children belonging to the partner at the time of union formation were assumed not to be shared.

The European FFS focused on respondents of childbearing age, but age limits varied across countries (Note 2). The two German samples were restricted to persons under 40. I therefore selected couples - married and coresident or cohabiting - in which the woman (whether the respondent or the partner) was under 40 and not pregnant. Couples in which one or the other partner is sterilized are included in the analysis. The primary reason for this is theoretical - sterilized couples have made a clear decision not to have more children. Excluding them would introduce selectivity in motivation to avoid childbearing among those who want no more children. Because countries included in the analysis have widely different levels and acceptability of contraceptive sterilization, the bias would not be uniform across countries. A secondary reason is to maintain comparability between analyses of childbearing desires and birth risks based on retrospective histories; because few surveys have information on the date of sterilization, and none have information on former partners' sterilization, sterilized couples have been included in the risk pool.

Previous analyses of stepfamily fertility in Europe have estimated separate models for male and female respondents. This was possible because units of analysis were birth intervals observed over each respondent's life course. At a fixed point in time, i.e., the interview, many fewer respondents are found in various stepfamily types. It was thus necessary to pool male and female respondents for analysis and was not possible to 
estimate potentially different effects of step-family configuration on the desires of men and women.

In each of the surveys, respondents were asked whether they wanted to have any (more) children. Although the exact wording of the question varied somewhat across countries, most of the questions were phrased in terms of want rather than intend or expect. Desires are ideal for purposes of identifying parity-specific motivations because, unlike intentions or plans, they do not incorporate perceptions of constraints on one's choice (Thomson 2002b). In most countries, the question implied an answer of yes or no and those few respondents who volunteered that they did not know or were unsure whether they wanted a child were coded as don't know. In others, the question offered a response option reflecting uncertainty. High proportions of don't know responses were reported in Slovenia (12.6\%), Latvia (14.8\%), East (18.3\%) and West Germany $(25.2 \%)$. I investigated the property of these responses with ordered logistic regression (SPSS) of childbearing desires among couples with only shared children. Estimated thresholds for don't know responses fell midway between those for no and yes responses in the two parts of Germany. In Slovenia, don't know responses were closer to yes, in Latvia closer to no. I used logistic regression (SPSS) to estimate models with two alternative measures of childbearing desires: contrasting yes responses to combined no and don't know; and excluding don't know responses to contrast respondents who answered yes versus no. As would be expected, if don't know represents a more favorable view of childbearing than no, effect sizes were usually larger when don't know responses were excluded, but the pattern of effects remained the same. Results are reported below for effects on the contrast of yes versus no.

As Table 1 demonstrates, key hypotheses about the relative value of motherhood and fatherhood require us to distinguish step-families in which only the woman has children, only the man has children, or both partners have children from prior unions. In previous analyses of life histories, sufficient numbers of respondents have experienced time in each of these states to provide at least a minimal test of differences between them. When we observe couples at a particular point in time, however, the number who began their union with such combinations of children will have shrunk due to the decision to have one or two children together. Even in countries with high proportions of step-families, we are unable to observe sufficient numbers without shared children to estimate different effects of the man or the woman or both already being a parent. Thus, my models include only the number of shared children, within combined parities one, two and three or more.

In all models, I controlled for the respondent's sex. Although men and women usually have similar desires for children (e.g. Jones and Brayfield 1997), sex differences in timing of unions and births, selection into step-families and reporting of children from prior unions could introduce associations between observed 
classifications of step-families and the respondent's sex. Only occasionally did sex have direct effects on childbearing desires, and these effects could be interpreted in relation to one or more of the sources just mentioned.

In addition to parity, a critical determinant of fertility desires, intentions or outcomes is age. One could argue that the older ages of partners in stepfamilies is part of the life course process that produces step-families and subsequent births, and should not be controlled in analysis of parity effects on childbearing desires. Nevertheless, it may not be the particular configuration of partners' children in step-families but the partners' ages that are the driving force in step-family fertility. In most countries, controlling for the woman's age produced larger effects of step-family configuration than when woman's age was not controlled. These results can be interpreted in terms of the countervailing influences of age and the value of shared children on a respondent's childbearing desires. Models presented below include the control for the linear effect of woman's age and two categorical variables representing non-normative age differences between woman and man: the man is more than two years younger than the woman; or more than 5 years older. Note that I do not include the couple's marital status (cohabiting or married) in these models. Decisions about marriage are likely endogenous to decisions about having a child; it would therefore be inappropriate to attempt to 'explain' childbearing desires in terms of marital status.

Only two indicators of socioeconomic status or social context were comparable across all seven data sets: respondent's education and size of place of residence. Respondent's education is represented in the FFS Standard Recode Files by three 'major' levels: less than secondary school, secondary school, post-secondary education (Note 3). Size of place was categorized in five levels in France and Austria: under $2,000,2,000-9,999,10,000-99,999,100,000-999,999$, and 1,000,000+. In other countries, the number of levels was three or four - for example, the bottom two categories were combined for Belgium and all countries other than France and Austria combined places of sizes 100,000 or more.

\section{Results}

Table 2 summarizes key features of pathways to step-family formation for each of the countries in the current analysis (Prskawetz et al. 2003). In the formerly socialist countries, step-families arise from high rates of childbearing in first unions. Under these conditions, step-family formation should vary according to rates of union dissolution and repartnering - lowest in Slovenia, highest in Latvia. The final column shows the percent of step-families identified in this analysis. The fact that East Germany surpasses Latvia in the proportion of families with stepchildren is due to high rates of 
childbearing before the first union among East German women. France, Finland and West Germany have lower rates of childbearing in first unions; thus, repartnering is not as likely to produce a step-family as in the formerly socialist countries. Austria, like East Germany and Slovenia, produces a substantial number of step-families through childbearing before first union as well as through high rates of union disruption and repartnering.

Table 2: $\quad$ Pathways to step-family formation, women born in 1952-1959

\begin{tabular}{|c|c|c|c|c|c|c|}
\hline \multirow[b]{2}{*}{ Country } & \multicolumn{4}{|c|}{ Percent experiencing life event by age 35 * } & \multirow{2}{*}{$\begin{array}{l}\text { Percent of } 2^{\text {nd }} \\
\text { unions with } \\
\text { pre-union child, } \\
\text { by age } 35^{*}\end{array}$} & \multirow{2}{*}{$\begin{array}{c}\text { Percent } \\
\text { couples in } \\
\text { step-families } \\
\text { at interview ** }\end{array}$} \\
\hline & $\begin{array}{c}1 \text { st } \\
\text { union }\end{array}$ & $\begin{array}{l}\text { 1st union } \\
\text { end }\end{array}$ & $\begin{array}{l}\text { 2nd } \\
\text { union }\end{array}$ & $\begin{array}{l}\text { Child at } \\
\text { 1st union } \\
\text { formation }\end{array}$ & & \\
\hline France & 94 & 20 & 13 & 4 & 58 & 17.6 \\
\hline Finland & 95 & 24 & 16 & 4 & 48 & 17.2 \\
\hline West Germany & 87 & 20 & 14 & 8 & 45 & 14.8 \\
\hline Austria & 94 & 23 & 15 & 13 & 53 & 23.9 \\
\hline Slovenia & 97 & 12 & 8 & 13 & 65 & 11.6 \\
\hline East Germany & 94 & 22 & 15 & 32 & 83 & 32.3 \\
\hline Latvia & 93 & 32 & 20 & 7 & 85 & 20.3 \\
\hline
\end{tabular}

* Source: Prskawetz, Vikat, Philipov and Engelhardt (2003) analysis of European FFS Fertility Surveys.

** Own Calculations, NOTE: Percent step-families defines children born within one year prior to a union as shared children, while Prskawetz et al. (2003) do not.

In Table 3, I present for each country the percent of families with only stepchildren or with stepchildren and shared children, within couples' combined parity (one, two, three or more). Among couples with one child, between five (Slovenia) and sixteen (Austria) percent have only a stepchild, i.e., the child of one or the other partner. Among couples with two children, it is more or equally likely that the couple has one shared and one stepchild as that they have two stepchildren. The proportion of twochild couples that are stepfamilies is very similar to the proportion of one-child families, except in East Germany, Austria and Slovenia where childbearing before first union is relatively common (Table 2). These 'extra' step-families are likely to be comprised of one child born to a single mother and a shared child. Most interesting are the last two rows of the table; among couples with three or more children altogether, a 
substantial proportion - in several countries nearly or more than half - are stepfamilies. Most of these step-families include a shared child. This means that a very common pathway to family sizes of three or more is through the formation of stepfamilies and step-family childbearing (Note 4).

Table 3: $\quad$ Family type by combined parity by country

\begin{tabular}{|c|c|c|c|c|c|c|c|}
\hline \multirow{2}{*}{$\begin{array}{l}\text { Combined } \\
\text { parity and } \\
\text { family } \\
\text { composition }\end{array}$} & \multicolumn{7}{|c|}{ Percent of couples with step- or step and shared children } \\
\hline & France & Finland & W. Germ. & Austria & Slovenia & E. Germ. & Latvia \\
\hline \multicolumn{8}{|l|}{ One child } \\
\hline Stepchild & 8.4 & 10.2 & 9.1 & 15.9 & 5.1 & 11.4 & 11.2 \\
\hline \multicolumn{8}{|l|}{ Two children } \\
\hline $\begin{array}{l}\text { Step and } \\
\text { shared }\end{array}$ & 7.1 & 6.2 & 6.5 & 11.4 & 6.6 & 16.0 & 10.3 \\
\hline Both steps & 3.1 & 6.6 & 4.2 & 7.2 & 1.8 & 8.4 & 4.4 \\
\hline \multicolumn{8}{|l|}{$\begin{array}{l}\text { Three + } \\
\text { children }\end{array}$} \\
\hline $\begin{array}{l}\text { Step and } \\
\text { shared }\end{array}$ & 27.3 & 24.1 & 24.0 & 34.9 & 27.3 & 60.7 & 34.0 \\
\hline All steps & 7.3 & 6.7 & 10.0 & 13.2 & 8.2 & 13.0 & 12.1 \\
\hline \# Couples & 1424 & 1884 & 1270 & 1933 & 2306 & 2261 & 1667 \\
\hline
\end{tabular}

Source: European Fertility and Family Surveys. N's are unweighted, percentages weighted.

Table 4 presents the relative odds of desiring another child for respondents with different numbers of shared children, among stepfamilies, compared to couples with only shared children. Analyses were conducted separately for couples with a combination of one, two and three or more children. Because of differences in the measurement of childbearing desires (see above), differences in effect sizes are of less interest than are their direction and difference from zero.

Among couples with one child, desires for second children do not depend on whether the first is a stepchild or a shared child, except in Latvia. Because second shared children produce sibling value (see Table 1), the result in most countries is not surprising.

Without exception, the odds of desiring a third child (combined parity) are higher when couples have no shared children than when they have two or one, among couples with two children altogether. The relative odds (compared to couples with two shared 
children) range from about two in West Germany - which has very low fertility and a high proportion of one-child families - to more than sixteen in East Germany. The lesser value of a full sibling is reflected in much smaller or non-significant relative odds for couples with one shared and one stepchild.

Table 4: $\quad$ Effects of step-family configuration on childbearing desires

\begin{tabular}{|c|c|c|c|c|c|c|c|}
\hline \multirow{2}{*}{$\begin{array}{l}\text { Combined and } \\
\text { shared parity }\end{array}$} & \multicolumn{7}{|c|}{$\begin{array}{l}\text { Relative odds of wanting a child } \\
\text { relative to couples with only shared children }\end{array}$} \\
\hline & France & Finland & W. Germ. & Austria & Slovenia & E. Germ. & Latvia \\
\hline \multicolumn{8}{|l|}{ One child } \\
\hline Not shared & 1.23 & 0.69 & 0.55 & 1.10 & 1.52 & 2.18 & 2.41 \\
\hline \multicolumn{8}{|l|}{ Two children } \\
\hline None shared & 8.86 & 4.16 & 2.17 & 5.19 & 5.93 & 16.33 & 10.93 \\
\hline One shared & 2.17 & 2.94 & 1.67 & 1.80 & 2.04 & 4.36 & 1.40 \\
\hline \multicolumn{8}{|l|}{$\begin{array}{l}\text { Three + } \\
\text { children }\end{array}$} \\
\hline None shared & 7.76 & 3.53 & 5.36 & 4.08 & 3.29 & 6.60 & 2.73 \\
\hline One shared & 9.88 & 1.08 & 1.66 & 2.03 & 1.05 & 2.07 & 1.14 \\
\hline Two+ shared & 2.55 & 0.59 & 0.57 & 1.91 & 0.76 & 0.79 & 0.82 \\
\hline \# couples & 1424 & 1884 & 1270 & 1933 & 2306 & 2261 & 1667 \\
\hline
\end{tabular}

Source: European Fertility and Family Surveys.

NOTE: Models include respondent's sex, woman's age in single years, age difference (man $>2$ years younger, $>5$ years older), respondent's education level, and size of place. Contrast is between yes and no responses, with don't know excluded. Relative odds in bold type are significantly different from $1(p<.05)$.

Among couples with three or more children combined, those without a shared child again have much higher odds of desiring another child. Only in France, are the odds of desiring a child also higher when the couple has only one or even when they have two or more shared children. In general, the costs of raising four or more children are overcome only when the couple would be having their first shared child.

Woman's age had negative effects on birth intentions in almost every analysis. Where significant, effects of having a non-normatively older or younger husband were consistent with the general age effect - younger husbands increased the odds of desiring a child, older husbands decreased the odds. Size of place had virtually no effect on childbearing desires, net of other variables, but respondent's education was almost always associated with higher odds of desiring another child. The single exception was in West Germany, where respondents with post-secondary education were less likely to want a third child (partners' children combined) than were those with less education. 


\section{Discussion and conclusions}

Step-family experience is common across Europe and becoming more so as younger generations experience high rates of union dissolution and repartnering during the childbearing years (Prskawetz et al. 2003). In many European countries, step-family fertility is a critical component of overall fertility, comprising a substantial proportion of third and higher-order births. Thus, the study of step-family fertility has become increasingly important to understanding fertility variation and change.

The reason for the production of 'extra' births in step-families is because several key benefits of having children are contingent on the partnership in which they are born. When partners remain together, at least through the childbearing years, they share the unique benefits of first (commitment, parental status values) and second (sibling value) shared children. Third and higher-order births provide no unique value and significantly increase childrearing costs; they are optional. But when parents dissolve their union and form new partnerships, their children no longer represent a shared commitment. Additional births are required to provide the same value for the new union. In addition, new partners may not yet have had children, creating further incentives to continue childbearing.

The evidence is overwhelming that couples are strongly motivated to have at least one shared child, even when they already have considerable childrearing responsibilities. In every country, among couples with two or more children altogether, the odds of wanting another child were at least twice as high for couples without shared children in comparison to couples with two or more shared children. Some of this difference may arise from the desires of a childless partner to have her/his own children, but most of it is likely to arise from the unique value of a first shared child for expressing the new couple's commitment, making them (and their child) a 'real family'.

Some evidence supports the sibling value of a second shared child. First is the absence of differences in desires between couples with one shared child and one stepchild. Even though they have one shared child already, couples are as likely as those who do not have a shared child to want another child. Second, in France, Finland, Slovenia and East Germany, couples with one shared child (among the two or more children they already have) are more likely than those with two or more shared children to want another child, even though the cost of rearing three children altogether is greater than the cost of rearing two.

An important caveat to these results is that the couple's combined parity may overestimate their childrearing costs. The key assumption of the parity specification used to infer unique values of first and second third children is that the costs of rearing $\mathrm{N}$ stepchildren are the same as those of rearing $\mathrm{N}$ shared children. If that is not true, then childbearing desires in step-families could be driven not by unique values but by 
lower costs of the children they already have. For example, a couple with two nonresident stepchildren might have virtually no childrearing responsibilities to weigh against the value of having a shared child. They would then be very likely to want a child, more so than couples with two shared children, with whom they are compared in this analysis. Most stepchildren do, however, entail some childrearing responsibility. Thus, it is not surprising that nonresident as well as resident stepchildren reduce the risk of a subsequent birth (Vikat, Thomson and Prskawetz 2003).

I want to emphasize that the parity specification used in this analysis is critical for understanding step-family fertility. When we model childbearing desires or birth risks as a function of shared children and stepchildren, we usually find negative effects of a second shared child as well as stepchildren. These results tell us only that childbearing desires and birth risks steadily and sometimes sharply decline after a couple has two children and that stepchildren add to the childrearing cost. By considering the couple's decision in the context of all of their children, as well as the number they share, we can test hypotheses about the unique values of first and second births, values that are key to maintaining replacement-level fertility in low-fertility societies.

\section{Acknowledgements}

My research on step-family fertility is the direct result of a stimulating year at Stockholm University's Demographic Unit and my lucky collaboration with its founder and former director, Jan M. Hoem. Data for this research were provided by the Population Activities Unit, United Nations Economic Commission for Europe (http://www.unece.org/ead/pau/). The research was supported by National Institute of Child Health and Human Development grant HD20491 and NICHD center grant HD05876. I am extremely grateful for the able research assistance of Anat Yom-Tov. 


\section{Notes}

1. Figures for the former GDR are likely inflated by counting all children born prior to a couple's co-residence as stepchildren; housing shortages often constrained a couple to live separately even when they were expecting a child. If children born within two years of a couple's co-residence are counted as shared children, estimates of stepfamily formation would remain as high as in other European countries with high rates of union dissolution and repartnering.

2. Dates of survey and ages of respondents varied: France (1994, 20-49); Finland (women 1989, 22-46, men 1992, 28-31, 34-38, 42-46); Germany (1992, 20-39); Austria (1995-96, 20-54); Slovenia (1994, 15-45), Latvia (1995, 18-49).

3. Ideally, we would like to distinguish effects of woman's versus man's education; France did not, however, collect data on partner's education.

4. Similar calculations can be made at the individual level; among men or women with three or more biological children and in a current union, up to a quarter (and in East Germany about 46 percent) have children from prior unions and the current union (data available on request). 


\section{References}

Buber, Isabella, and Prskawetz, Alexia, 2000. "Fertility in second unions in Austria: Findings from the Austrian FFS." Demographic Research 3 (2). Available http://www.demographic-research.org/volumes/vol3/2.

Bulatao, Rodolfo A., 1981. "Values and disvalues of children in successive childbearing decisions." Demography 18 (1): 1-25.

Bumpass, Larry L., 1984. "Some characteristics of children's second families." American Journal of Sociology 90 (3): 608-623.

Fawcett, James T., 1983. "Perceptions of the value of children: Satisfactions and costs." In: Bulatao, Rudolfo A., and Lee, Ronald D. (eds), Determinants of Fertility in Developing Countries Vol 2: Supply and Demand for Children. Academic Press, New York: 429-457.

Griffith, Janet D., Koo, Helen P., and Suchindran, C. M., 1985. "Childbearing and family in remarriage." Demography 22 (1): 73-88.

Henz, Ursula, 2002. "Childbirth in East and West German step-families." Demographic Research 7 (6): 307-342. Available http://www.demographicresearch.org/volumes/vol7/6.

Hoem, Britta, 1995. "Kvinnors och män's liv, Del 2, Parbildning och separationer [Women's and men's lives, Part 2, Union formation and separation]." Demografiska Rapporter 2.2. Statistics Sweden, Stockholm.

Kreyenfeld, Michaela, 2003. "Crisis or adaptation - reconsidered: A comparison of East and West German fertility patterns in the first six years after the 'Wende'." European Journal of Population 19 (4): 303-329.

Jones, Rachel K., and Brayfield, April, 1997. ''Life's greatest joy?' European attitudes toward the centrality of children." Social Forces 75 (4): 1239-1270.

Lillard, Lee A., and Waite, Linda J., 1993. "A joint model of marital childbearing and marital disruption." Demography 30 (4): 653-681.

Loomis, Laura S., and Landale, Nancy S., 1994. "Nonmarital cohabitation and childbearing among black and white American women." Journal of Marriage and the Family 56 (4): 949-62.

Oláh, Livia Sz., 2001. "The first shared birth in second unions in Sweden and Hungary: A gender perspective." Unpublished manuscript. Demographic Unit of the Stockholm University, Stockholm. 
Prskawetz, Alexia, Vikat, Andres, Philipov, Dimiter, and Engelhardt, Henriette, 2003. "Pathways to stepfamily formation in Europe: Results from the FFS." Demographic Research 8 (5): 107-149. Available http://www.demographicresearch.org/volumes/vol8/5.

Stewart, Susan D., 2002. "The effect of stepchildren on childbearing intentions and births." Demography 39 (1): 181-197.

Thomson, Elizabeth, 1997. "Her, his and their children: Influences on couple childbearing decisions." National Survey of Families and Households Working Paper \# 76. Center for Demography and Ecology of the University of Wisconsin-Madison. Available http://www.ssc.wisc.edu/cde/nsfhwp/nsfh76.pdf.

Thomson, Elizabeth, 2002a. "Value of children." In: Smelser, Neil J., and Baltes, Paul B. (eds), International Encyclopedia of the Social and Behavioral Sciences. Elsevier, New York.

Thomson, Elizabeth, 2002b. "Family size preferences." In: Smelser, Neil J., and Baltes, Paul B. (eds), International Encyclopedia of the Social and Behavioral Sciences. Elsevier, New York.

Thomson, Elizabeth, and Li, Jui-Chung Allen, 2002. "Her, his, and their children: childbearing intentions and births in stepfamilies." National Survey of Families and Households Working Paper \# 89. Center for Demography and Ecology at the University of Wisconsin - Madison. Available http:// www.ssc.wisc.edu /cde/nsfhwp/nsfh89.pdf.

Thomson, Elizabeth, et al., 2002. "Childbearing in stepfamilies: How parity matters." In: Klijzing, Erik, and Corijn, Martine (eds), Fertility and Partnership in Europe: Findings and Lessons from Comparative Research. Volume II. United Nations, Geneva and New York.

Toulemon, Laurent, 1997. "The fertility of step-families: The impact of childbearing before the current union." Paper presented at the Annual Meeting of the Population of America, Washington D.C.

Toulemon, Laurent, and LaPierre-Adamchk, Evelyne, 1995. "Demographic patterns of motherhood and fatherhood in France." Paper for the IUSSP anthropology and demography committee seminar on fertility and the male life cycle in the era of fertility decline, November 1995, Zacarecas.

United Nations Economic Commission for Europe, 2003. Fertility and Family Surveys, Population Activities Unit. Available http://www.unece.org/ead/pau/ffs/, $19^{\text {th }}$ November 2003. 
Vikat, Andres, Thomson, Elizabeth, and Hoem, Jan M., 1999. "Step-family fertility in contemporary Sweden: The impact of childbearing before the current union." Population Studies 53 (2): 211-25.

Vikat, Andres, Thomson, Elizabeth, and Prskawetz, Alexia, 2004. "Childrearing responsibility and step-family fertility in Finland and Austria." European Journal of Population 20 (1): 1-21.

Wineberg, Howard, 1990. "Childbearing after Remarriage." Journal of Marriage and the Family 52 (1): 31-38. 